\title{
PENGARUH PELANGGARAN HAK PATEN TERHADAP PENGGUNA SMARTPHONE
}

Kiki Anggraini

165100120P

Fakultas Komputer, 448757186

Kikianggraini.student@umitra.ac.id

\begin{abstract}
Penelitian ini membahas beberapa kasus pertikaian pelanggaran hak paten dari dua vendor smartphone. Beberapa Negara Asia, Eropa dan Amerika sudah mulai membatas industribusi produk yang melanggar hak paten namun pembatasan belum terjadi di Indonesia. Oleh sebab itu penelitian utama dari makalah ini adalah mengenai pengaruh pelanggaran hak paten Smartphone terhadap pengguna Smartphone di Indones ia dengan memanfaatkan metode survey. Data responden yang diperoleh melalui proses pengujian reliabilitas, validitas, dan korelasi menggunakan software SPSS. Perhitungan yang dilakukan berdasarkan lima faktor yang diuji mempunyai dampak besar dalam penelitian ini.

Definisi kata paten itu sendiri, konsep paten mendorong inventor untuk membuka pengetahuan demi kemajuan masyarakat dan sebagai gantinya, inventor mendapat hak eksklusif selama periode tertentu. Mengingat pemberian paten tidak mengatur siapa yang harus melakukan invensi yang dipatenkan, sistem paten tidak dianggap sebagai hak monopoli. Pemberian hak paten bersifat teritorial, yaitu, mengikat hanya dalam lokasi tertentu. Dengan demikian, untuk mendapatkan perlindungan paten di beberapa negara atau wilayah, seseorang harus mengajukan aplikasi paten di masing-masing negara atau wilayah tersebut.
\end{abstract}

Kata Kunci : Hak paten,Smartphone,Pelanggaran 


\section{A. INTRODUCTION}

Kebutuhan media

telekomunikasi saat ini sudah menjadi kebutuhan yang dianggap penting bagi sebagian masyarakat, khususnya masyarakat perkotaan. Berbagai kemudahan dan kemutakhiran teknologi ditawarkan pada produk-produk

smartphone. Kehadiran Smartphone di masyarakat bukanlah hal yang baru, dan hampir semua kalangan mengetahui handphone

tersebut.Berbagai layanan ditingkatkan baik pada teknologinya maupun pada layanannya untuk mendapatkan konsumen yang

loyal pada produk smartphone, fiturfitur lengkap dan harga yang bervariasi dari ponsel pintar inilah yang menjadi incaran konsumen yang semakin melek teknologi. Persaingan yang ketat memberikan keuntungan bagi konsumen untuk menentukan pilihan yang sesuai. Pilihan produk dengan merek ternama merupakan pertimbangan konsumen dalam mengambil keputusan membeli smartphone. Merek merupakan salah satu faktor penting bagi konsumen sebagai jaminan akan mutu dan kualitas produk yang dihasilkan. Sebagian ponsel yang popular di pasaran berasal dari merek yang sudah tidak asing terdengar ditelinga konsumen. Oleh karena itu vendor dalam merilis produk baru perlu menerapkan strategi yang kreatif untuk bertahan di pasar yaitu dengan melakukan paten produk. Fitur-fitur serta layanan pada smartphone dapat dilindungi dengan hak paten seperti yang dilakukan oleh Apple dan Samsung. Beberapa waktu terakhir, dunia teknologi khususnya smartphone sedang disibukkan oleh pertikaian Apple dan Samsung sehubungan dengan produk yang dipasarkannya melanggar paten masing-masing vendor meskipun pada kenyataannya banyak vendor lain yang melanggar. Beberapa fitur yang diajukan sebagai pelanggaran oleh Samsung terhadap Paten yang dimiliki Apple antara lain Bounce Back, single scroll/pinch to zoom, tap to zoom, iPhone front, iPhone back, iPhone home screen dan 
iPad design. Pihak Samsung juga mengajukan pelanggaran paten yang menurut mereka dilanggar oleh Apple yaitu Notificatio Center pada perangkat iOS. Banyak pembahasan yang bermuara pada pembelaan dari masing-masing vendor di wilayah kekuasaannya, antara lain beberapa Negara yaitu Samsung memenangkan gugatannya di Korea dan Jepang sedangkan di Jerman, Australia dan Amerika dimenangkan oleh Apple. Adanya permasalahan pelanggaran hak paten yang terjadi, berpengaruh terhadap penggunaan produk salah satu vendor di Negara yang menyatakan kalah. Namun belum ada penelitian secara kualitatif atau kuantitatif mengenai hal diatas dikarenakan masalah pelanggaran paten ini masih baru. Akan tetapi kami mencoba untuk melakukan penelitian mengenai dampak dari permasalahan pelanggaran paten produk smartphone Apple dan Samsung bagi pengguna yang ada di Indonesia.

\section{HAK PATEN}

Berdasarkan UU No. 14 Tahun 2001 Pasal 1 yang dimaksud Paten adalah hak eksklusif yang diberikan oleh Negara kepada Inventor atas hasil Invensinya di bidang teknologi, yang untuk selama waktu tertentu melaksanakan sendiri Invensinya tersebut atau memberikan persetujuannya kepada pihak lain untuk melaksanakannya. Paten diberikan untukjangka waktu selama 20 (duapuluh) tahun terhitung sejak Tanggal Penerimaan dan jangka waktu itu tidak dapat diperpanjang.

\section{SMARTPHONE}

Secarah arfiah smartphone merupakan PDA (Personal Data Assistant) yang memiliki layar warna dan kemampuan audio serta telepon. Smartphone adalah computer palm top dan telepon seluler yang dikemas menjadi satu.

\section{Kasus Pelanggaran Paten}

Banyak pelanggaran yang terjadi dalam hal paten namum kasus pelanggaran paten yang diangkat 
kedalam penelitian ini adalah kasus yang terjadi antara Apple dan Samsung. Berikut ini beberapa hasil pertarungan pada pengadilan di beberapa Negara:

\section{Pengadilan Kore a Se latan}

Di Seoul, Samsung mengajukan gugatan pada bulan Juni 2011 di Pengadilan Distrik Pusat mengutip lima pelanggaran paten. Pada akhir Agustus 2012 sebuah panel tiga hakim di Pengadilan Distrik Pusat Seoul memutuskan bahwa Apple melanggar dua paten teknologi Samsung, sementara Samsung melanggar salah satu paten Apple. Pengadilan memberikan ganti rugi kecil untuk kedua perusahaan dan memerintahkan penghentian sementara penjualan dari produk yang melanggar di Korea Selatan, meskipun produk yang dilarang bukanlah model terbaru dari Samsung ataupun Apple. Pengadilan Distrik Pusat Seoul memutuskan bahwa Samsung melanggar salah satu paten utilitas Apple, apa yang disebut efek "bounceback (bangkit kembali)" di IOS, dan bahwa Apple telah melanggar dua paten wireless Samsung. Klaim Apple bahwa Samsung menyalin desain iPhone dan iPad ditolak. Pengadilan juga memutuskan bahwa "tidak ada kemungkinan" bahwa konsumen akan bingung smartphone Samsung dan Apple, dan bahwa ikon smartphone Samsung tidak melanggar hak paten Apple.

\section{Pengadilan Je pang}

Keluhan Samsung di Pengadilan Distrik Tokyo Jepang menyebutkan dua pelanggaran. Apple telah mengajukan gugatan paten lainnya di Jepang melawan Samsung, terutama satu fitur "Bounce-Back".

Samsung juga telah menuntut Apple, mengklaim iPhone dan iPad melanggar paten Samsung. Pada Jumat, 31 Agustus 2012, Pengadilan Distrik Tokyo memutuskan bahwa smartphone Samsung Galaxy dan tablet tidak melanggar paten Apple pada teknologi yang mensinkronisasikan musik dan video antara device dan server. Tiga hakim di Jepang juga memberikan gantirugi yang akan dikembalikan kepada 
Samsung. Hakim Tamotsu Shoji mengatakan: "Produk terdakwa tidak tampak seperti mereka menggunakan teknologi yang sama seperti produk-produk penggugat sehinggakita mengecilkan

pengaduan yang dibuat oleh Apple." Juru bicara yang tidak disebutkan namanya untuk Samsung mengatakan: "Kami akan terus menawarkan produk-produk yang sangat inovatif untuk konsumen, dan melanjutkan kontribusi kami terhadap pengembangan industri mobile." Ronald A. Cass, konsultan hukum dan mantan wakil ketua Komisi Perdagangan Internasional, berkomentar: "Saya tidak akan berharap ada banyak pertimbangan seperti ini." Quote berdasarkan putusan dari pengadilan Amerika bukan pengadilan Jepang yang mengacu pada bagaimana sengketa paten didengar oleh juri.

\section{Definis Paten}

Kata Paten, diambil dari bahasa Inggris yaitu patent, yang awalnya berasal dari kata patere yang artinya membuka diri (untuk pemeriksaan publik), dan juga berasal dari istilah letters patent, yaitu surat keputusan yang dikeluarkan kerajaan yang memberikan hak eksklusif kepada individu dan pelaku bisnis tertentu.

Inventor adalah seseorang yang secara sendiri atau beberapa orang yang secara bersama-sama melaksanakan ide yang dituangkan kedalam kegiatan yang menghasilkan invensi.

Pemilik karya intelektual disebut dengan istilah inventor. Inventor bisa dilakukan secara individu maupun kelompok. Inventor lebih mudah mendapatkan hak paten atas hasil penemuan karya intelektual mereka. Sedangkan untuk diluar inventor terlebih dahulu memperoleh pengalihan hak secara tertulis dari sang inventor.

Pemegang Paten adalah inventor sebagai pemilik paten atau hak paten yang menerima hak tersebut dari pemilik atau pihak lain yang menerima lebih lanjut hak paten tersebut, dan terdaftar dalam daftaran umum paten tersebut. 


\section{B. CONCLUSION}

Terdapat beberapa faktor yang mempengaruhi pengguna smartphone tetap menggunakan merk Samsung meskipun telahterjadi pertikaian dengan Apple mengenai hak paten. Faktor yang diambil lebih pada 'kualitas layanan' pemilik merk terhadap pengguna smartphone, yang dapat mempengaruhi life style dan lingkungan sekitar. Definisi kata paten itu sendiri, konsep paten mendorong inventor untuk membuka pengetahuan demi kemajuan masyarakat dan sebagai gantinya, inventor mendapat hak eksklusif selama periode tertentu. Mengingat pemberian paten tidak mengatur siapa yang harus melakukan invensi yang dipatenkan, sistem paten tidak dianggap sebagai hak monopoli. Pemberian hak paten bersifat teritorial, yaitu, mengikat hanya dalam lokasi tertentu. Dengan demikian, untuk mendapatkan perlindungan paten di beberapa negara atau wilayah, seseorang harus mengajukan aplikasi paten di masing-masing negara atau wilayah tersebut.

Beberapa Negara Asia, Eropa dan Amerika sudah mulai membatas industribusi produk yang melanggar hak paten namun pembatasan belum terjadi di Indonesia. Oleh sebab itu penelitian utama dari makalah ini adalah mengenai pengaruh pelanggaran hak paten Smartphone terhadap pengguna Smartphone di Indonesia dengan memanfaatkan metode survey.

Maka banyak pelanggaran paten pelanggaran yang terjadi dalam hal paten namum kasus pelanggaran paten yang diangkat kedalam penelitian ini adalah kasus yang terjadi antara Apple dan Samsung. Berikut ini beberapa hasil pertarungan pada pengadilan di beberapa Negara yang terlibat dalam pelanggaran paten.

\section{ACKNOWLEDGEMENT University Of Indonesia University Of Mitra Indonesia Telkom University University Of Mellbourne Saitama University}


D. REFERENCE(Based ISO 690 )

[1] A. S. Putra And O. M. Febriani, "Knowledge Management Online Application In Pdam Lampung Province," In Prosiding International Conference On Information Technology And Business (Icitb), 2018, Pp. 181-187.

[2] A. S. Putra, O. M. Febriani, And B. Bachry, "Implementasi Genetic Fuzzy System Untuk Mengidentifikasi Hasil Curian Kendaraan Bermotor Di Polda Lampung," J. Sist. Inf. Dan Manaj. Basis Data, Vol. 1, No. 1, Pp. 21-30, 2018.

[3] O. M. Febriani And A. S. Putra, "Sistem Informasi Monitoring Inventori Barang Pada Balai Riset Standardisasi Industri Bandar Lampung," J. Inform., Vol. 13, No. 1, Pp. 90-98, 2014.

[4] Putra, Arie Setya. "2018 Artikel Struktur Data, Audit Dan Jaringan Komputer." (2018).

[5] Putra, A. S. (2018, July 17). Paperplain Fundamental Create Application With Borland Delphi 7.0 University Of Mitra Indonesia. Retrieved From Osf.Io/Pbrn9.

\section{E. REFERENCE $($ Based APA)}

Putra, A. S., Aryanti, D. R., \& Hartati, I. (2018, November). Metode SAW (Simple Additive Weighting) sebagai Sistem Pendukung Keputusan Guru Berprestasi (Studi Kasus: SMK Global Surya). In Prosiding Seminar Nasional Darmajaya (Vol. 1, No. 1, pp. 85-97).

Sari, D. P., Febriani, O. M., \& Putra, A. S. (2018, November). Perancangan Sistem Informasi SDM Berprestasi pada SD Global Surya. In Prosiding Seminar Nasional Darmajaya (Vol. 1, No. 1, pp. 289-294).

Putra, A. S. (2018). Paperplain: Execution Fundamental Create Application With Borland Delphi 7.0 University Of Mitra Indonesia.

Putra, A. S., Sukri, H., \& Zuhri, K. Sistem Monitoring Realtime Jaringan Irigasi Desa (JIDES) Dengan Konsep Jaringan Sensor Nirkabel. IJEIS (Indonesian Journal of Electronics and Instrumentation Systems), 8(2), 221232.

Darmawan, A., Yuliawati, D., Marcella, O., \& Firmandala, R. (2016). Sistem Absensi dan Pelaporan Berbasis Fingerprint dan SMS Gateway. EXPLORE, 7(1).

Febriani, O. M., Wahyuni, T., \& Yusuf, S. (2017). DESIGN OF WEBSITE-BASED INFORMATION SYSTEM FOR EDOCUMENT ADMINISTRASI IN THE COMMUNITY SERVICE UNIT (A Case Study at Rajabasa District). INTERNATIONAL JOURNAL OF 
COMPUTERS \& TECHNOLOGY, 16(7), 7010-7020.

Febriani, O. M., \& Wahyuni, T. (2017, October). PERANCANGAN SISTEM E-DOCUMENT ADMINISTRASI LOGBOOK PENELITIAN PADA UNIT LAYANAN DI BANDAR LAMPUNG. In Prosiding Seminar Nasional Darmajaya (Vol. 1, No. 1, pp. 187-194).

Febriani, O. M., \& Permadi, A. B. (2017). Implementasi Sistem Aplikasi Data Bimbingan dan Pelanggaran Siswa pada Sekolah Menengah Atas di Lampung Tengah dengan Metode Analisis dan Desain Sistem Terdistribusi (SSAD). EXPERT, 7(1).

Febriani, O. M., \& Ambarwati, L. (2015). PERANCANGAN APLIKASI PENGOLAHAN DATA PENJUALAN UKM KELANTING KHAS TELO DESA SIDOHARJO KECAMATAN JATI AGUNG KABUPATEN LAMPUNG SELATAN. Jurnal Teknologi Informasi dan Bisnis Pengabdian Masyarakat Darmajaya, 1(1), 77-95.

Febriani, O. M. (2015). Rancang Bangun Aplikasi Ecommercemenggunakan Freewebstore pada UKM Kelanting di Desa Sidoharjo Lampung Selatan. Prosiding Sembistek 2014, 1(02), 446-458. 